УДК 338.49:656

\title{
СТРАТЕГІЧНІ НАПРЯМИ РОЗВИТКУ ІНФРАСТРУКТУРИ ЗАЛІЗНИЧНОГО ТРАНСПОРТУ В УМОВАХ ТРАНСКОРДОННОГО СПІВРОБІТНИЦТВА
}

\author{
Корінь М.В., д.е.н., доцент, \\ Кондратюк М.В., к.е.н., доцент, \\ Войтов I.М., ст. викладач, \\ Король К.В., магістр (УкрДУЗТ)
}

В статті вивчено підходи до визначення змісту категорії «транскордонне співробітництво» та проаналізовано існуючі класифікаиії його видів. Доповнено класифікацію видів транскордонного співробітництва залізничного транспорту. Розкрито взаємозв'язок пріоритетів розвитку інфраструктури залізничного транспорту $і$ иілей-иінностей сочіально-економічного зростання регіонів у рамках транскордонного співробітництва. Визначено стратегічні напрями розвитку інфраструктури залізничного транспорту в межах транскордонного регіону.

Ключові слова: інфраструктура, залізничний транспорт, транскордонне співробітництво, класифікація, напрями.

\section{СТРАТЕГИЧЕСКИЕ НАПРАВЛЕНИЯ РАЗВИТИЯ ИНФРАСТРУКТУРЫ ЖЕЛЕЗНОДОРОЖНОГО ТРАНСПОРТА В УСЛОВИЯХ ТРАНСГРАНИЧНОГО СОТРУДНИЧЕСТВА}

Коринь М.В., о.э.н., доцент, Кондратюк М.В., к.э.н., доцент, Войтов И.Н., ст. преподаватель, Король К.В., магистр (УкрГУЖТ)

B статье изучены подходы $\kappa$ определению содержания категории «трансграничное сотрудничество» и проанализированы существующие классификации его видов. Дополнена классификация видов трансграничного сотрудничества железнодорожного транспорта. Раскрыта взаимосвязь приоритетов развития инфраструктуры железнодорожного транспорта и иелей-ценностей социальноэкономического роста регионов в рамках трансграничного сотрудничества. Определены стратегические направления развития инфраструктуры железнодорожного транспорта в пределах трансграничного региона.

Ключевые слова: инфраструктура, жселезнодорожный транспорт, трансграничное сотрудничество, классификация, направления. 


\title{
STRATEGIC DIRECTIONS FOR THE DEVELOPMENT OF RAILWAY TRANSPORT INFRASTRUCTURE IN THE CONTEXT OF CROSS- BORDER COOPERATION
}

\author{
Korin M., doctor of economics sciences, associate professor, \\ Kondratyuk M. V., candidate of economic sciences, associate professor, \\ Voytov I.M., senior lecturer, \\ Korol K., master (USURT)
}

The article examines the views of scientists on the definition of the content of the category "cross-border cooperation", which made it possible to establish the existence of political, program-Project, regional, integration, sociological, realistic and "ConflictCooperation" approaches to understanding this concept. The existing models and forms of development of cross-border cooperation are studied. The classification of types of crossborder railway transport cooperation has been supplemented with the following features: 1) project implementation duration: one-time, long-term; 2) the form of implementation of cooperation: transport communication, virtual interaction, localization of production; 3) the nature of relations: formal, informal; 4) groups of projects of strategic cross-border cooperation of railway transport: projects for the development of freight transport and logistics, projects for the development of passenger transport, infrastructure development projects, traction services development projects, production and service development projects. Examples of infrastructure projects implemented on the basis of cross-border cooperation are given. The interrelation of priorities for the development of railway transport infrastructure and goals-values of socio-economic growth of regions within the framework of cross-border cooperation is revealed. Strategic directions for the development of railway transport infrastructure within a cross-border region are defined. It is proved that the development of railway transport infrastructure within cross-border regions should occur at the expense of: first, improving interoperability with EU railways; second, expanding virtual interaction; third, stimulating the creation of localized production facilities; fourth, the growth of the quality and availability of transport and logistics services within cross-border regions.

Keywords: infrastructure, railway transport, cross-border cooperation, classification, directions.

Актуальність дослідження. залізниць призвело до зростання Включення залізничного транспорту дивергентності стану i параметрів iї України до системи глобальних функціонування принципам i умовам інфраструктурних коридорів розвитку та діяльності залізниць $Є С$, а відповідно й його повноцінне входження в обумовило наростання проявів Транс'європейську транспортну мережу СС інфраструктурних асиметрій. В ситуації на сьогоднішній день, перш за все, катастрофічного дефіциту коштів АТ залежить від здатності галузі реалізувати «Укрзалізниця» немає власних інфраструктурні проєкти, орієнтовані на можливостей для реалізації стратегічних впровадження високошвидкісного руху для галузі інфраструктурних проєктів поїздів і європейських стандартів якості розвитку і потребує залучення технологій, обслуговування, забезпечення інтероперабельності з залізницями Європи. Адже постійне недофінансування процесів модернізації та оновлення інфраструктури ресурсів i компетенцій підприємствпартнерів з транскордонних регіонів.

Аналіз останніх досліджень та публікацій. Розробленню інструментарію

Вісник економіки транспорту і промисловості № 70-71, 2020 
та пошуку шляхів розвитку інфраструктури залізничного транспорту присвятили свої публікації такі провідні вчені вітчизняної наукової школи, як Ю.Т. Боровик, В.Л. Дикань, Г. Д. Ейтутіс, Ю.В. Єлагін, О.Г. Кірдіна, В.О. Овчиннікова, О.М. Полякова, I.B. Токмакова та інші [1-5]. Всебічному дослідженню проблематики розвитку транскордонних зв'язків присвятили свої публікації В. Балабанова, К. Верхоланцевої, В. Засадко, Н. Мікула тощо [6-11]. Високо оцінюючи наукові здобутки вище зазначених вчених 3 даної проблематики, слід зауважити, що в умовах активного впровадження в Україні інструментів політики «Східного партнерства» створюється й можливість для відродження потенціалу інфраструктури залізниць за рахунок поглиблення інфраструктурного співробітництва в транскордонних регіонах. Це i актуалізує доцільність визначення стратегічних напрямів інфраструктурного

АТ «Укрзалізниця»

B

розвитку умовах

транскордонного співробітництва.

Саме тому метою сmammi $\epsilon$ удосконалення теоретичних положень i визначення стратегічних напрямів розвитку інфраструктури залізничного транспорту в умовах транскордонного співробітництва.

Виклад основного матеріалу. Одним із елементів політики регіонального економічного розвитку країн $\mathrm{EC} \mathrm{на}$ сьогодні виступає транскордонне співробітництво, що реалізується за рахунок усебічної інтеграції і поглиблення локальних прикордонних зв'язків, спільної участі у проєктах покращення соціальноекономічного становища країн i регіонів. Стрімкому зростанню явища транскордонного співробітництва не лише в Європі, а й сусідніх 3 нею державах сприяли саме ті процеси глобалізації, регіоналізації, трансформації геоекономічних відносин, що призвели до зміни розширення впливу ЄС на політичній карті світу. Сьогодні для країн Європи транскордонне співробітництво означає не лише розвиток прикордонних територій, а й створення інтегрованого європейського простору без кордонів.

Слід зазначити, що розвитку транскордонного співробітництва в Європі сприяло визначення його політичної ролі в забезпеченні інтеграції регіонів i розроблення ефективного правового підгрунтя для реалізації прикордонної співпраці. Окрім Європейської рамкової конвенції про транскордонне співробітництво між територіальними або владами Ради Європи та прийнятого у 1995 році доповнення до неї у виглядів Додаткового протоколу, нормативноправову базу для транскордонного співробітництва створюють, схвалені в 1989 році «Декларація про транскордонне співробітництво в Європі», у 1992 році «Європейська хартія регіональних мов і меншин» і в 1993 році «Віденська декларація голів держав і урядів - членів Ради Європи», а також ряд таких документів у сфері регіоналізації, як «Декларація Асамблеї європейських регіонів щодо регіоналізму в Свропі» (1996 рік) i проєкт Європейської Хартії про регіональне самоврядування (1997 рік) [10, c. 138-170]. Саме ці нормативно-правові акти визначили зміст, форми, типи та інструменти реалізації транскордонного співробітництва, створивши тим самим інституційний базис розвитку процесів транскордонної співпраці в Європі. Аналізуючи зміст транскордонного співробітництва, що наводиться в ряді нормативно-правових i програмних документі, слід вказати, що в більшості 3 них визначення сутності даної категорії грунтується на наведеному ще в Мадридській Конвенції про транскордонне співробітництво між територіальними общинами або властями. понятті. Це вказує на те, що саме даний документ $\epsilon$ законоформуючим базисом для розвитку транскордонного співробітництва, згідно 3 яким розвиваються зв'язки і формуються довірчі відносини між регіонами. Основні підходи до визначення категорії «транскордонне співробітництво» подано в табл. 1.

Вісник економіки транспорту і промисловості № 70-71, 2020 
Таблиия 1

Підходи до визначення категорії «транскордонне співробітництво» (сформовано на основі робіт [7; 11])

\begin{tabular}{|c|c|c|}
\hline Назва підходу & Ключові ознаки & Автор \\
\hline Політичний & політичні мотиви держави & 3. Петренко \\
\hline Програмно-проєктний & $\begin{array}{c}\text { співробітництво через } \\
\text { конкретні програми, } \\
\text { проєкти }\end{array}$ & $\begin{array}{c}\text { В. Пила, О. Чмир, } \\
\text { О. Гарасюк, Т. Терещенко }\end{array}$ \\
\hline Регіональний & $\begin{array}{c}\text { співробітництво в межах } \\
\text { державних кордонів }\end{array}$ & $\begin{array}{l}\text { О. Урбан, П. Бєлєнький, } \\
\text { Н. Мікула, І. Артьомов }\end{array}$ \\
\hline Інтеграційний & $\begin{array}{c}\text { інтеграція, співробітництво, } \\
\text { міждержавні зв'язки }\end{array}$ & $\begin{array}{c}\text { К. Балабанов, В. Дергачов, } \\
\text { А. Зборовська }\end{array}$ \\
\hline Соціологічний & культурні взаємозв’язки & $\begin{array}{l}\text { А. Краснейчук, } \\
\text { К. Верхоланцева }\end{array}$ \\
\hline Реалістичний & $\begin{array}{c}\text { збереження суверенітету і } \\
\text { дотримання законності }\end{array}$ & $\begin{array}{l}\text { А. Краснейчук, } \\
\text { К. Верхоланцева }\end{array}$ \\
\hline «Конфлікт-співробітництво» & $\begin{array}{c}\text { співробітництво для } \\
\text { вирішення конфліктів }\end{array}$ & $\begin{array}{l}\text { А. Краснейчук, } \\
\text { К. Верхоланцева }\end{array}$ \\
\hline
\end{tabular}

Різноманітність аспектів співпраці в рамках транспортного співробітництва зумовила існування й різних видів реалізації такого роду співпраці. Найбільш узагальнену класифікацію пропонує О. М. Літвішко, виділяючи види транскордонного співробітництва за такими ознаками $[8$, с. 18-19]: 1) за функціональною сферою реалізації: у сфері екології, планування простору і стійкого розвитку, транспорту і комунікацій, економіки, зайнятості і туризму, освіти і культури, досліджень та інновацій, населення прикордонних територій; 2) залежно від діапазону та рівня розвитку: транскордонні регіони, робітничі спільноти, малі регіони, Свропейська група 3 територіального співробітництва; 3) залежно від географічної форми функціонування: європейський, азіатський, американський i пострадянський види транскордонного співробітництва; 4) залежно від інтеграційних мотивів: політико-правове та економічне (території взаємодоповнюваності економік і території подолання сировинної орієнтації економік).

Науковці вказують на те, що транскордонна співпраця реалізується через різного роду моделі та форми співробітництва. Так, у науковій літературі найбільш поширеною точкою зору щодо моделей реалізації транскордонного співробітництва $є$ підхід, запропонований К. Верхоланцевою, за яким залежно від ступеня розвитку транскордонного співробітництва автор виділяє бар'єрну, градієнтну, контактну та інтегративну модель [7]. За ознакою суб'єктів ініціаторів А. Макаревич виділяє моделі «м'якого» та «жорсткого» регіоналізму [12]. А О. М. Литвишко доповнюе дану класифікаційну ознаку моделей транскордонного співробітництва моделями висхідної та спадної інтеграції [8]. Н. Огнева пропонує класифікувати моделі транскордонного співробітництва залежно від напрямів, виділяючи депресивну (носить обмежений характер співпраці), класичну (грунтується на домінуванні одного регіону над іншим) i партнерську (передбачає взаємну співпрацю на паритетних основах) [13].

Що стосується форм реалізації транскордонного співробітництва, то в цьому питанні серед науковців також не існує єдиної точки зору. На законодавчому рівні (Закон України «Про транскордонне

Вісник економіки транспорту і промисловості № 70-71, 2020 
співробітництво») до організаційних форм транскордонного співробітництва віднесено єврорегіони, контакти суб'єктів транскордонної співпраці, угоди в певних галузях та інші форми [14]. Колектив авторів, Н. Мікула та В. Засадко, вказують на еволюційний характер розвитку процесів транскордонного співробітництва i виділяють залежно від цілей, завдань, масштабу i характеру такі його форми: одноразові контакти, довгострокова транскордонна співпраця, транскордонна діяльність на основі стратегії (концепції) i співробітництво незалежних учасників співпраці [9, с. 20]. Такого роду підхід до форм організації та реалізації транскордонного співробітництва має досить узагальнений характер i не відображує змісту і засади розвитку транскордонних контактів. Розуміючи це, дані науковців у власному монографічному дослідженні досить детально характеризують такі форми транскордонного співробітництва, як транскордонна угода, єврорегіон, європейські угрупування територіального співробітництва, єврорегіонального об'єднання транскордонний кластер, транскордонна міграція, транспорт кордонні промислові зони, транскордонна торгівля, клондайкінг і транскордонні партнерства [9].

Отже,

транскордонне

співробітництво $€$ свого роду процесом налагодження зв'язків у рамках не лише територіально наближених прикордонних регіонів, але й економічних об'єднань і суб'єктів різних рівнів управління з метою реалізації спільних угод, проєктів і програм у стратегічно важливих сферах економічної діяльності.

Виходячи 3 особливостей реалізації транскордонного співробітництва і сучасних умов функціонування залізничного транспорту i враховуючи існуючі підходи до класифікації його видів доповнимо класифікацію транскордонного співробітництва залізничного транспорту такими ознаками: 1) тривалість реалізації проєктів: одноразове, тривале; 2) форма реалізації співробітництва: транспортне сполучення, віртуальна взаємодія, локалізація виробництв; 3) характер зв'язків: формальний, неформальний; 4) групи проєктів стратегічної транскордонної співпраці залізничного транспорту: проєкти розвитку вантажних перевезень і логістики, проєкти розвитку пасажирських перевезень, проєкти розвитку інфраструктури, проєкти розвитку послуг тяги, проєкти розвитку виробництва i сервісу [3].

Україна також активно використовує транскордонне співробітництво в якості інструменту розвитку $\mathrm{i}$ забезпечення конкурентоспроможності регіонів, що задекларовано в таких програмних документах, як Державна стратегія регіонального розвитку на період до 2020 року та Державна програма розвитку транскордонного співробітництва на 20112015 роки [15 - 16]. Географічно знаходячись на перетині важливих торговельних шляхів, Україна підтримує транскордонні зв'язки в межах прикордонних територій як 3 європейськими країнами, так і $з$ колишніми радянськими державами. Окрім розвитку співробітництва в межах укладених дво- та багатосторонніх угод, найбільш реалізованою формою транскордонної співпраці в країні $є$ єврорегіони. Наразі в Україні діє 10 єврорегіонів у рамках яких прикордонні території співпрацюють 3 регіонами сусідніх країн у різних сферах соціально-економічного розвитку.

$\mathrm{He}$ менш важливе значення для розвитку транскордонних зв'язків регіонів України мають i такі програмні інструменти підтримки співробітництва, як «Свропейський інструмент сусідства та партнерства», Ініціатива «Східне партнерство» та Програма «Підтримка політики регіонального розвитку України».

Окремо заслуговують на увагу ті транскордонні проєкти співробітництва, що орієнтовані на стимулювання прогресивного розвитку сфери транспорту. Попри те, що переважно транскордонні

Вісник економіки транспорту і промисловості № 70-71, 2020 
проєкти співробітництва орієнтовані на покращення прикордонної інфраструктури, у ряді як європейських, так й інших країнсуб'єктів транскордонної співпраці вже сьогодні існує величезний досвід реалізації масштабних інфраструктурних проєктів на засадах транскордонного співробітництва. Зокрема найбільш показовим у цьому аспекті $\epsilon$ приклад реалізації проєктів розвитку інфраструктури транспорту в рамках транскордонного співробітництва між Німеччиною, Польщею, Данією та Швецією. У межах єврорегіону «Померанія» транспортні ініціативи країнпартнерів сприяли відновленню німецькопольської поромної переправи та мережі водних каналів, створенню в Щецині станції обслуговування пасажирської поїздів далекого сполучення та модернізації двох прикордонних аеропортів [17]. Не менш масштабні інфраструктурні проєкти були реалізовані і в рамках регіону «Верхній Рейн», де за ініціативи країнпартнерів споруджено два термінали в міжнародному аеропорту Базель - Мюлуз Фрайбург, модернізовано ряд ділянок залізничної інфраструктури, побудовано залізничний міст та інтермодальний логістичний центр, забезпечено інтероперабельність залізничної інфраструктури на кордонах 3 французькими та швейцарськими залізничними системами [18].

Таким чином, транскордонне співробітництво можна розглядати в якості ефективного інструменту реалізації спільних інфраструктурних проєктів, що дозволить не лише якісно змінити стан транспортного комплексу транскордонних регіонів, але й забезпечити досягнення ряду синергетичних ефектів у процесі їхньої реалізації.

В основі розвитку інфраструктури залізничного транспорту на засадах транскордонного співробітництва, 3 авторської точки зору, мають знаходитися такі теоретичні положення [19]:
- по-перше, в основі розвитку інфраструктури залізничного транспорту в рамках транскордонного регіону знаходиться інноваційно-технологічне партнерство залізниць, регіональних i місцевих органів влади, бізнесу, що реалізується шляхом прийняття узгоджених рішень 3 метою досягнення структурнотехнологічних трансформацій і конвергенції рівня розвитку інфраструктури залізниць транскордонних регіонів. Така співпраця грунтується на взаємній підтримці та стимулюванні процесів реалізації спільних інфраструктурних проєктів в транскордонних регіонах;

$$
\text { по-друге, }
$$

забезпечення структурно-технологічних трансформацій i конвергенції рівня розвитку інфраструктури залізниць транскордонних регіонів досягається шляхом локалізації інноваційних виробництв у регіонах співробітництва, орієнтованих на реалізацію крупних інфраструктурних проєктів на залізничному транспорті України. Для цього має бути сформовано інституційні засади та організаційний механізм транскордонної виробничої співпраці, орієнтований на залучення новітніх технологій i реалізацію виробничого потенціалу підприємств галузі;

по-третє, стимулом для активізації процесів розвитку інфраструктури залізниць у межах транскордонних регіонів на засадах їхнього інноваційнотехнологічного партнерства $€$ існуючий взаємозв'язок між цілями-цінностями соціально-економічного розвитку регіонівпартнерів i пріоритетами розвитку інфраструктури залізниць. Грунтуючись на цьому, доцільно розкрити взаємозв'язок пріоритетів розвитку інфраструктури залізничного транспорту і цілей-цінностей соціально-економічного зростання транскордонних регіонів (рис. 1). 


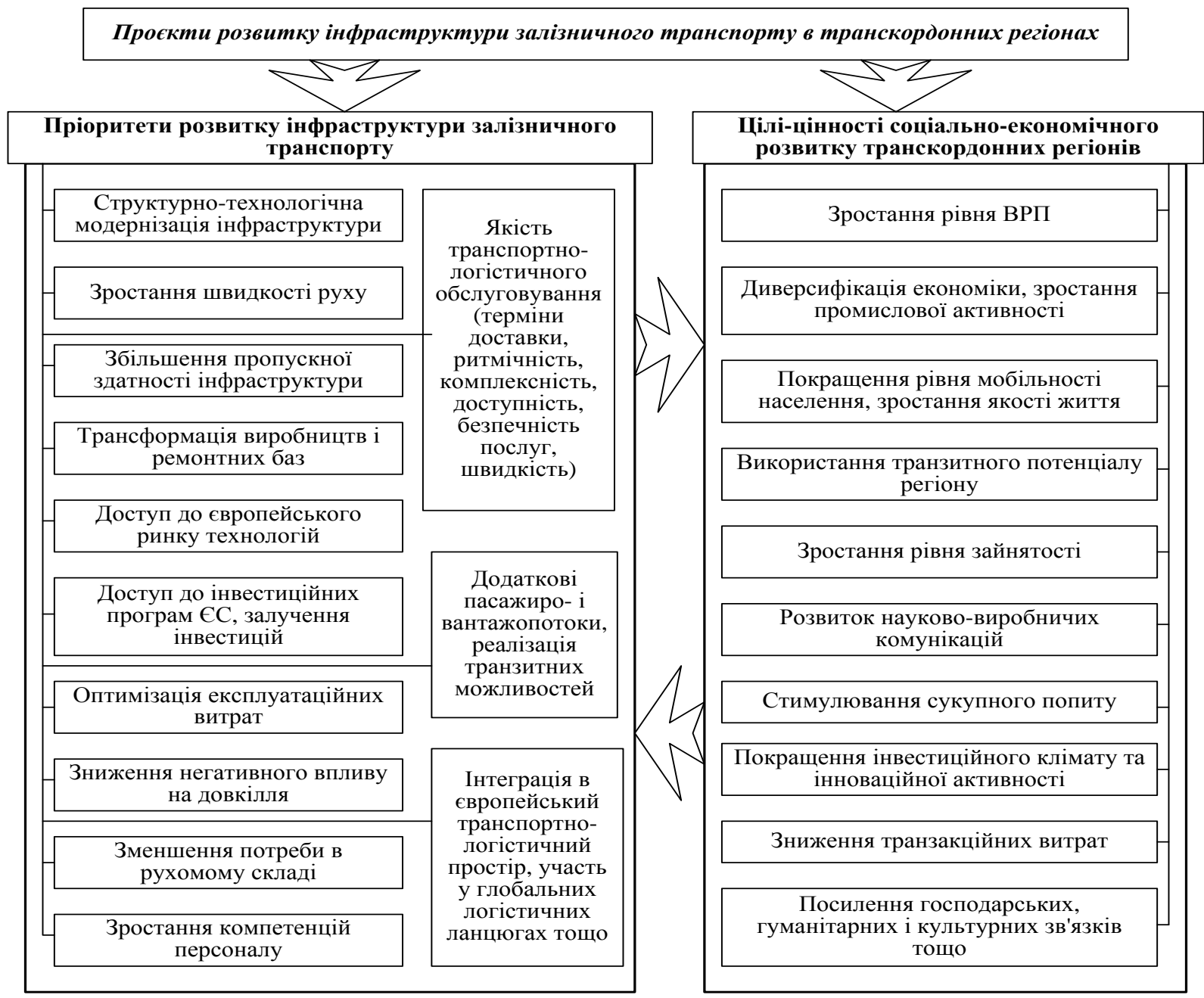

Рис. 1. Концептуальна схема взаємозв'язку пріоритетів розвитку інфраструктури залізничного транспорту і иілей-цінностей сочіально-економічного зростання регіонів у рамках транскордонного співробітництва

Враховуючи встановлений взаємозв'язок між пріоритетами розвитку інфраструктури залізничного транспорту і цілями соціально-економічного зростання регіонів у рамках транскордонного співробітництва, доцільно представити стратегічні напрями розвитку інфраструктури АТ «Укрзалізниця» в межах транскордонного регіону, що відповідають сучасним принципам постіндустріального розвитку (рис. 2). Відповідно до останніх розвиток інфраструктури АТ «Укрзалізниця» в рамках транскордонних регіонів має відбуватися за рахунок: по-перше, покращення інтероперабельності 3 залізницями $\mathrm{EC}$; по-друге, розширення віртуальної взаємодії; по-третє, стимулювання створення локалізованих виробництв; по-четверте, зростання якості і доступності транспортно-логістичних послуг в рамках транскордонних регіонів. Так, основними напрямами розвитку інфраструктури залізничного транспорту в межах транскордонного регіону за умови створення локалізованих виробництв i поглиблення віртуальної транспортнологістичної взаємодії визначено:

- розвиток мультимодальних i нових контейнерних маршрутів;

- створення транскордонної транспортно-логістичної інфраструктури;

- будівництво роботизованих

складських комплексів і безпілотного 
«розумного» рухомого складу;

- налагодження електронного обігу

та електронної комерції;

- створення цифрових виробництв

і ремонтних баз;

- організацію високошвидкісного

руху, електрифікацію ділянок залізниць і будівництво Smart-вокзалів; додатків;

- створення мобільних платформ i

- організацію

сезонних

пасажирських маршрутів i туристичних сервісів тощо.

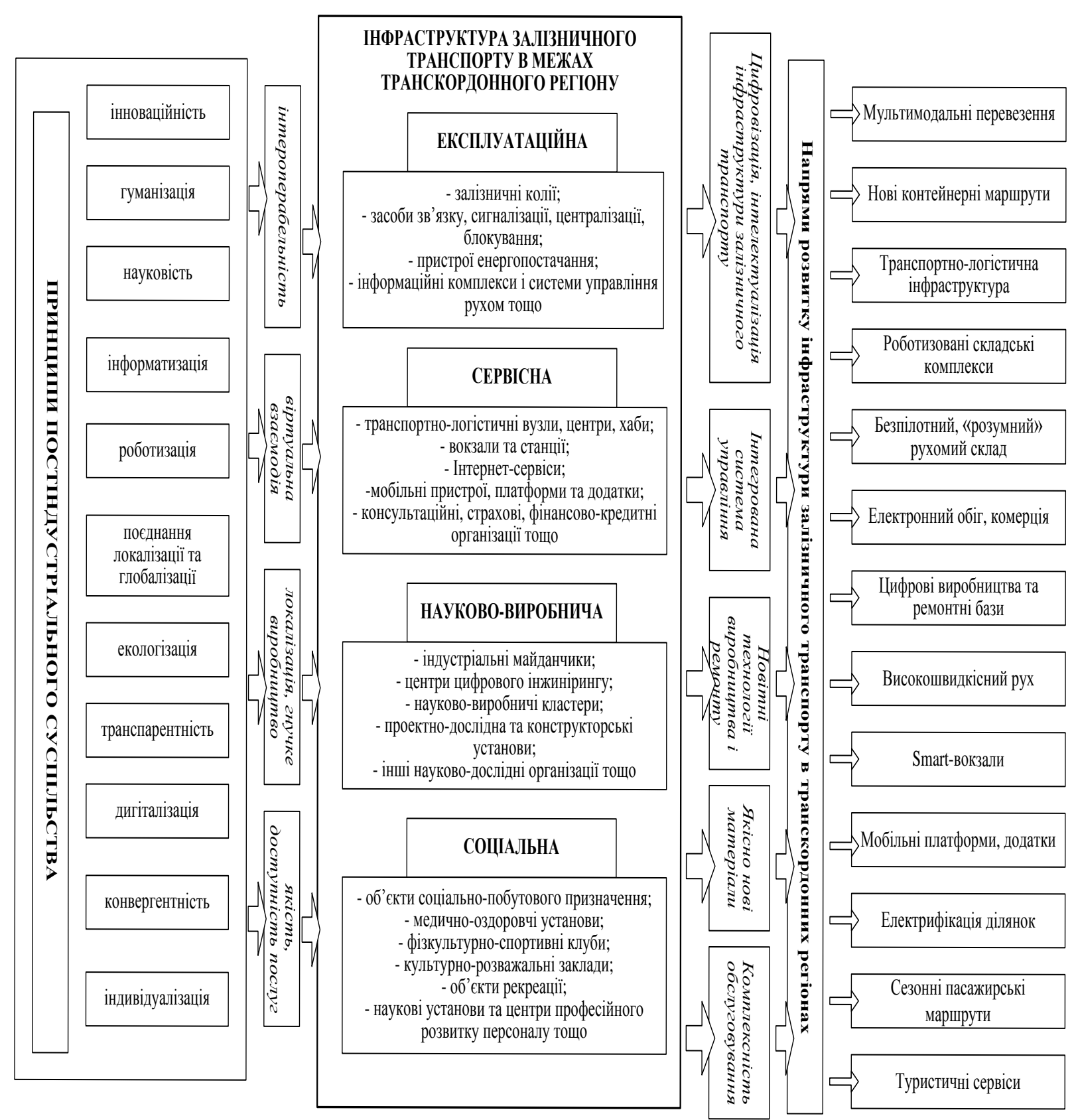

Рис. 2. Стратегічні напрями розвитку інфраструктури залізничного транспорту в межах транскордонного регіону

Висновок. Таким чином, в статті співробітництво», що дозволило вивчено погляди науковців на визначення встановити існування змісту категорії

«транскордонне

програмно-проєктного, політичного, регіонального,

Вісник економіки транспорту і промисловості № 70-71, 2020 
інтеграційного, реалістичного

соціологічного, співробітництво» підходів до розуміння даного поняття. Досліджено існуючі моделі i форми розвитку транскордонного співробітництва. Доповнено класифікацію видів транскордонного співробітництва залізничного транспорту такими ознаками: 1) тривалість реалізації проєктів: одноразове, тривале; 2) форма реалізації співробітництва: транспортне сполучення, віртуальна взаємодія, локалізація виробництв; 3) характер зв'язків: формальний, неформальний; 4) групи проєктів стратегічної транскордонної співпраці залізничного транспорту: проєкти розвитку вантажних перевезень і логістики, проєкти розвитку пасажирських перевезень, проєкти розвитку інфраструктури, проєкти розвитку послуг тяги, проєкти розвитку виробництва i сервісу. Розкрито взаємозв'язок пріоритетів розвитку інфраструктури залізничного транспорту і цілей-цінностей соціально-економічного зростання регіонів у рамках транскордонного співробітництва та визначено стратегічні напрями розвитку інфраструктури залізничного транспорту в межах транскордонного регіону. Доведено, що розвиток інфраструктури залізничного транспорту в рамках транскордонних регіонів має відбуватися за рахунок: по-перше, покращення інтероперабельності з залізницями СС; подруге, розширення віртуальної взаємодії; по-третє, стимулювання створення локалізованих виробництв; по-четверте, зростання якості i доступності транспортно-логістичних послуг в рамках транскордонних регіонів.

\section{СПИСОК ВИКОРИСТАНОЇ ЛІТЕРАТУРИ}

1. Дикань В. Л., Кірдіна О. Г. Система інтегрованого управління інвестиційно-інноваційним розвитком залізничного транспорту. Маркетинг $i$ менеджмент інноващій. 2011. № 1. С. 137144.
2. Ейтутіс Г. Д., Крищенко С. О., Зіць О. Є. Характеристика світових моделей управління інфраструктурою залізничного транспорту. Економіка та суспільство. 2017. № 9. : веб-сайт. URL: http://www.economyandsociety.

in.ua/journal/9_ukr/70.pdf (дата звернення: 24.02.2019).

3. Овчиннікова В.О. Стратегічне управління розвитком залізничного транспорту України: монографія. Харків: УкрДУЗТ, 2017. 426 с.

4. Боровик Ю. Т., Слагін Ю. В., Полякова О. М. Форми стратегічного партнерства при реалізації проектів розвитку залізничної інфраструктури. Вісник економіки транспорту $i$ промисловості. 2019. № 68. С. 75-84.

5. Токмакова I. В. Теоретикометодологічні основи забезпечення гармонійного розвитку залізничного транспорту України: дис. на здобуття наук. ступеня докт. екон. наук; спеціальність: 08.00 .03 / Укр. держ. ун-тет залізничного транспорту. Харків, 2015. 456 с.

6. Балабанов К.В. Проблеми інтеграції України у світовий економічний простір: монографія. Донецьк: «Вебер», 2007. $234 \mathrm{c}$.

7. Верхоланцева К.С. Развитие современного трансграничного сотрудничества России и стран Европы: сравнительный характер : автореф. дис. ... канд. полит. наук : 23.00.04. Москва, 2009. $25 \mathrm{c}$.

8. Литвишко О.М. Трансграничное сотрудничество как механизм обеспечения национальных интересов современной России в Каспийском регионе: автореф. дисс. на соиск. учен. степени канд. полит. наук; специальность: 23.00.04. Пятигорск, 2015. $29 \mathrm{c}$.

9. Мікула Н., Засадко В. Транскордонне співробітництво України в контексті євроінтеграції: монографія Київ: НІСД, 2014. $316 \mathrm{c.}$

10. Студенніков I. Регіональна політика в країнах Європи: Уроки для України; за ред. С. Максименка. К.: Логос,

Вісник економіки транспорту і промисловості № 70-71, 2020 
2000. $171 \mathrm{c}$.

11. Краснейчук А.О. Теоретикометодологічні засади розвитку транскордонного співробітництва. Вісник НАДУ. 2014. № 3. С. 18-26.

12. Makarychev

A.

Regionostroitelstvo: kontseptualnyye konteksty / A. Makarychev. Region-building: conceptual contexts. 2002. № 4. URL: http://www.kazanfed.ru/publications/kazanfede ralist/n4/stat2 (Last accessed: 14.02.2018).

13. Огнева Н. Организационные аспекты развития трансграничного сотрудничества : веб-сайт. URL: teoriapractica.ru/rus/

files/arhiv_zhurnala/.../ogneva.pdf (дата обращения: 10.12.2017).

14. Про транскордонне співробітництво: Закон України від 24.06 .2004 р. №. 1861-IV. Законодавство України : веб-сайт. URL: http://zakon0.rada.gov.ua/laws/show/1861-15 (дата звернення: 29.12.2017).

15. Про затвердження Державної стратегії регіонального розвитку на період до 2020 року: постанова Кабінету Міністрів України від 6 серпня 2014 р. № 385. Законодавство Украӥни : веб-сайт. URL: http://zakon1.rada.gov.ua/laws/show/3852014-\%D0\%BF вата звернення: 19.08.2017).

16. Про затвердження Державної програми розвитку транскордонного співробітництва на 2011-2015 роки : постанова Кабінету Міністрів України від 1 грудня 2010 р. № 1088. Законодавство України : веб-сайт. URL: http://zakon2.rada.gov.ua/laws/show/10882010-\%D0\%BF (дата звернення: 19.08.2017).

17. Euroregion Pomerania: офіційний сайт. URL: http://www.pomerania.net (дата звернення: 19.10.2017).

18. Euregio Rhein-Waal: офіційний сайт. URL: http://www.euregio.org (дата звернення: 19.10.2017).

19. Корінь М.В. Розвиток інфраструктури залізничного транспорту в умовах співробітництва: монографія. Харків: УкрДУЗТ, 2019. 401 с.

\section{REFERENCES}

1. Dykan' V. L., Kirdina O. H. (2011). Systema intehrovanoho upravlinnya investytsiyno-innovatsiynym rozvytkom zaliznychnoho transportu [System of integrated management of investment and innovation development of railway transport]. Marketynh i menedzhment innovatsiy. № 1 . pp. 137-144.

2. Eytutis H. D., Kryshchenko S. O., Zits' O. YE. (2017). Kharakterystyka svitovykh modeley upravlinnya infrastrukturoyu zaliznychnoho transportu [Characteristics of world models of railway transport infrastructure management]. Ekonomika ta suspil'stvo. № 9. URL: http://www.economyandsociety. in.ua/journal/9_ukr/70.pdf. (in Ukrainian)

3. Ovchynnikova V.O. (2017). Stratehichne upravlinnya rozvytkom zaliznychnoho transportu Ukrayiny [Strategic management of railway transport development in Ukraine]: monohrafiya. Kharkiv: UkrDUZT. 426 p. (in Ukrainian)

4. Borovyk YU. T., Yelahin YU. V., Polyakova O. M. (2019). Formy stratehichnoho partnerstva pry realizatsiyi proektiv rozvytku zaliznychnoyi infrastruktury [Forms of strategic partnership in the implementation of railway infrastructure development projects]. The bulletin of Transport and Industry Economics. № 68. pp. 75-84. (in Ukrainian)

5. Tokmakova I. V. (2015). Teoretykometodolohichni osnovy zabezpechennya harmoniynoho rozvytku zaliznychnoho transportu Ukrayiny [Theoretical and methodological bases of ensuring the harmonious development of railway transport of Ukraine]: dys. na zdobuttya nauk. stupenya dokt. ekon. nauk; spetsial'nist': 08.00.03 / Ukr. derzh. un-tet zaliznychnoho transportu. Kharkiv. 456 p. (in Ukrainian)

6. Balabanov K.V. (2007). Problemy intehratsiyi Ukrayiny u svitovyy ekonomichnyy prostir [Problems of Ukraine's

Вісник економіки транспорту і промисловості № 70-71, 2020 
integration into the world economic space]: monohrafiya. Donets'k: «Veber». 234 p. (in Ukrainian)

7. Verkholantseva K.S. (2009). Razvytye sovremennoho trans hranychnoho sotrudnychestva Rossyy y stran Evropy: sravnytel'nyy kharakter [Development of modern cross-border cooperation between Russia and European countries]: avtoref. dys. ... kand. polyt. nauk : 23.00.04. Moskva. 25 p. (in Russian)

8. Lytvyshko O.M. (2015). Transhranychnoe sotrudnychestvo kak mekhanyzm obespechenyya natsyonal'nykh ynteresov sovremennoy Rossyy v Kaspyyskom rehyone [Cross-border cooperation as a mechanism for ensuring the national interests of modern Russia in the Caspian region]: avtoref. dyss. na soysk. uchen. stepeny kand. polyt. nauk; spetsyal'nost': 23.00.04. Pyatyhorsk. 29 p. (in Russian)

9. Mikula N., Zasadko V. (2014). Transkordonne spivrobitnytstvo Ukrayiny $\mathrm{v}$ konteksti yevrointehratsiyi [Ukraine's crossborder cooperation in the context of European integration]: monohrafiya Kyyiv: NISD. 316 p. (in Ukrainian)

10. Studennikov I. (2000). Rehional'na polityka v krayinakh Yevropy: Uroky dlya Ukrayiny [Regional Policy in Europe: Lessons for Ukraine]; za red. S. Maksymenka. K.: Lohos. 171 p. (in Ukrainian)

11. Krasneychuk A.O. (2014). Teoretyko-metodolohichni zasady rozvytku transkordonnoho spivrobitnytstva [Theoretical and methodological principles of cross-border cooperation]. Visnyk NADU. № 3. pp. 18-26. (in Ukrainian)

\section{Makarychev}

Regionostroitelstvo:

konteksty [Регіональне будівництво: концептуальні контексти]. Region-building: conceptual contexts. № 4 . URL: http://www.kazanfed.ru/publications/kazanfed eralist/n4/stat2 (Last accessed: 14.02.2018).

13. Ohneva N. Orhanyzatsyonnye aspekty razvytyya trans.hranychnoho sotrudnychestva [Organizational aspects of the development of cross-border cooperation]. URL: teoria-practica.ru/rus/ files/arhiv_zhurnala/.../ogneva.pdf. (in Russian)

14. Pro transkordonne spivrobitnytstvo [On cross-border cooperation]: Zakon Ukrayiny vid 24.06.2004 r. №. 1861-IV. Zakonodavstvo Ukrayiny : veb-sayt. URL: http://zakon0.rada.gov.ua/laws/show/1861-15. (in Ukrainian)

15. Pro zatverdzhennya Derzhavnoyi stratehiyi rehional'noho rozvytku na period do 2020 roku [On approval of the State Strategy for Regional Development until 2020]: postanova Kabinetu Ministriv Ukrayiny vid 6 serpnya 2014 r. № 385. Zakonodavstvo Ukrayiny : veb-sayt. URL: http://zakon1.rada.gov.ua/laws/show/3852014-\%D0\%BF. (in Ukrainian)

16. Pro zatverdzhennya Derzhavnoyi prohramy rozvytku transkordonnoho spivrobitnytstva na 2011-2015 roky [On approval of the State Program for the Development of Cross-Border Cooperation for 2011-2015]: postanova Kabinetu Ministriv Ukrayiny vid 1 hrudnya 2010 r. № 1088. Zakonodavstvo Ukrayiny. URL: http://zakon2.rada.gov.ua/laws/show/1088-

2010-\%D0\%BF (in Ukrainian).

17. Euroregion Pomerania: ofitsiynyy sayt. URL: http://www.pomerania.net.

18. Euregio Rhein-Waal: ofitsiynyy sayt. URL: http://www.euregio.org.

19. Korin' M.V. (2019). Rozvytok infrastruktury zaliznychnoho transportu v umovakh transkordonnoho spivrobitnytstva [Development of railway transport infrastructure in the conditions of cross-border cooperation]: monohrafiya. Kharkiv: UkrDUZT. 401 p. (in Ukrainian). 